\title{
New records of occurrence of five species of Neosilba (Diptera: Lonchaeidae) in the State of Bahia, Brazil
}

\author{
Novos registros de ocorrência de cinco espécies de Neosilba (Diptera: Lonchaeidae) para o \\ Estado da Bahia, Brasil
}

\author{
Maria Aparecida Leão Bittencourt ${ }^{\mathrm{I}}$ Adriano Murielle Santos de Menezes ${ }^{\mathrm{I}}$ \\ João Pedro de Andrade Bomfim ${ }^{\mathrm{I}}$ Olivia Oliveira dos Santos ${ }^{\mathrm{II}}$ Maria Aparecida Castellani ${ }^{\mathrm{II}}$ \\ Pedro Carlos Strikis ${ }^{\text {II }}$
}

\section{- NOTA -}

\begin{abstract}
This paper reports the record of new species of Neosilba in the State of Bahia: Neosilba bella Strikis \& Prado; Neosilba cornuphallus Strikis; Neosilba dimidiata (Curran); Neosilba ilheuense Strikis and Neosilba pseudozadolicha Strikis. Frugivorous flies were captured by McPhail traps, using a hydrolyzed protein at $5.0 \%$, as attractant, and also obtained of fruits samples of native and exotic plant species, which were collected in domestic orchards in the South of Bahia. The specimens of Lonchaeidae were identified according to MCALPINE \& STEYSKAL (1982), STRIKIS \& PRADO (2006) and STRIKIS (2011).
\end{abstract}

Key words: Tephritoidea, frugivorous flies, host plant.

\section{RESUMO}

Este trabalho refere-se a novos registros de espécies de Neosilba no estado da Bahia: Neosilba bella Strikis \& Prado; Neosilba cornuphallus Strikis; Neosilba dimidiata (Curran); Neosilba ilheuense Strikis e Neosilba pseudozadolicha Strikis. Moscas frugivoras foram capturadas em armadilhas do tipo McPhail, tendo como atrativo alimentar proteína hidrolisada a 5,0\%, e também obtidas de amostras de frutos de espécies vegetais nativas e exóticas, coletadas em pomares domésticos na região Sul do Estado da Bahia. Os espécimes de Lonchaeidae foram identificados de acordo com McALPINE \& STEYSKAL (1982), STRIKIS \& PRADO (2006) e STRIKIS (2011).

Palavras-chave: Tephritoidea, moscas frugívoras, planta hospedeira.

The genus Neosilba comprises 30 described species distributed mainly in Neotropical region (McALPINE \& STEYSKAL, 1982; STRIKIS
\& PRADO, 2005, 2008, 2009; STRIKIS \& LERENA, 2009; STRIKIS, 2011).

Some species of this genus are known to cause injuries in commercial fruits in Brazil causing commercial losses. Some crops attacked by Neosilba species are Barbados cherry (Malpighia emarginata) (ARAUJO \& ZUCCHI, 2002), coffee (Coffea arabica) (AGUIAR-MENEZES et al., 2007), orange (Citrus sinensis) (UCHÔA-FERNANDES et al., 2003), peach (Prunus persica) (MONTES et al., 2010), tangerine (Citrus reticulate) (LOPES et al., 2007), umbu-cajazeira (Spondias sp.) (SANTOS et al., 2004), and leaf buds of cassava (Manihot esculenta) (LOURENÇÃO et al., 1996), and other fruit species (RAGA et al., 2011). In Santa Catarina, Southern Brazil, Neosilba species were associated to many fruits species (GARCIA \& NORRBOM, 2011). In the state of Bahia the following species of Neosilba recorded are: $N$. zadolicha McAlpine \& Steyskal (SANTOS et al., 2004), N. certa (Walker), $N$. glaberrima (Wiedemann), $N$. parva (Hennig) and N. pendula (Bezzi) (BITTENCOURT et al., 2006).

The main purpose of this study was to report new records of species of Neosilba as well as some of its hosts in the state of Bahia. McPhail traps $(n=10)$ were used to capture Tephritoidea flies in commercial crops in the municipalities of

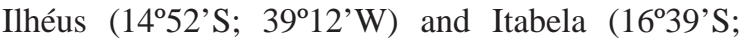
$\left.39^{\circ} 29^{\prime} \mathrm{W}\right)$, hydrolysed protein (5\%) was used as

IUniversidade Estadual de Santa Cruz (UESC), Rodovia Jorge Amado, Km 16, 45662-900, Ilhéus, BA, Brasil. E-mail: malbitte@uesc.br.

*Autor para correspondência.

IIUniversidade Estadual do Sudoeste da Bahia (UESB), Vitória da Conquista, BA, Brasil.

IIIPesquisador, Americana, SP, Brasil. 
attractant and was substituted weekly. In these crops the most common fruits were barbados cherry (Malpighia punicifolia, Malpighiaceae), mombin fruits (Spondias purpurea, Anacardiaceae), papaya (Carica papaya, Caricaceae), yellow passion fruit (Passiflora edulis f. flavicarpa, Passifloraceae), guajava (Psidium guajava) and Surinan cherry (Eugenia uniflora) from Myrtaceae family. Also, many ripe fruits or almost ripe, of many species were randomly collected in domestic orchards in the South of Bahia during the year of 2003 until 2009. The insects trapped and those that emerged from puparia were kept in $70 \%$ alcohol. The specimens of Lonchaeidae were identified according to MCALPINE \& STEYSKAL (1982), STRIKIS \& PRADO (2006) and STRIKIS (2011). The species sampled were the following ones: Neosilba bella Strikis \& Prado; Neosilba cornuphallus Strikis; Neosilba dimidiata (Curran); Neosilba ilheuense Strikis and Neosilba pseudozadolicha Strikis.

Male specimens of $\boldsymbol{N}$. bella were captured in traps in Itabela $(n=7)$ and Ilhéus $(n=1)$; also emerged from puparia reared from fruits of arazá fruit (Eugenia stipitata, Myrtaceae) $(\mathrm{n}=1)$ collected in the municipality of Camamu (135's; 39²11'W), from Barbados cherry $(n=2)$ collected in the municipality

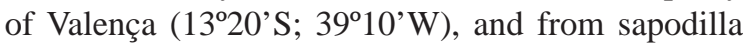
(Achras zapota, Sapotaceae) $(\mathrm{n}=1)$ collected in the

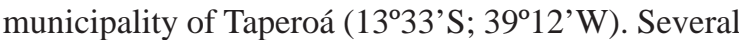
hosts families of this species were recorded, among them; Malpighiaceae, Myrtaceae e Sapotaceae (STRIKIS \& PRADO, 2008). $N$. bella has a wide geographical distribution in Brazil, it is present in the states of São Paulo, Rio de Janeiro, Espírito Santo, Amapá, Roraima, Goiás, Mato Grosso do Sul and Bahia, in many different biomes, ranging from Mata Atlântica, Amazon rain forest, and Cerrado. Its plasticity in occupying such different biomes and in attacking different hosts makes this species a candidate in becoming an important pest, once it is found in environments occupied by crops plantation, specially coffee (STRIKIS \& PRADO, 2006; AGUIAR MENEZES et al., 2007).

From fruits of sapodilla two specimens of $N$. dimidiata were recovered. This specie is known to occur in fruits of the families Annonaceae and Sapotaceae (QUERINO et al., 2010; UCHÔA, 2012), and is known to occur in Amazon, São Paulo, Amapá, Roraima, Rio de Janeiro and Espírito Santo States (STRIKIS, unpublished data) in forested and humid areas.

Only one specimen of $\boldsymbol{N}$. pseudozadolicha was recovered from fruit of arazá fruit; this species have been recorded from fruits of Fabaceae in the Northwest of the state of Pernambuco and Malpighiaceae in the North of the state of Roraima (STRIKIS, 2011).

Only one specimen of $\boldsymbol{N}$. cornuphallus was recovered from fruit of cashew (Anacardium occidentale, Anacardiaceae) collected in the

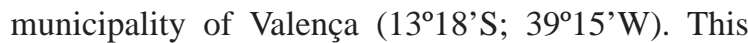
specie is known to occur in fruits of the following families Annonaceae, Anacardiaceae, Fabaceae, Rosaceae, Rutaceae, Rubiaceae, Ulmaceae e Verbenaceae (STRIKIS, 2011).

This is the first record of $\boldsymbol{N}$. ilheuense $(n=1)$; this species was collected in August 2011 in a McPhail trap placed in the Campus of the Universidade Estadual de Santa Cruz of Ilhéus (1447'S; 39¹0’W); the trap was placed close to a Passifloraceae crop. Neosilba ilheuense belongs to the same cryptic complex of species as $N$. peltae, $N$. mcalpiniei and $N$. parapeltae, although caught in a trap, it is possible that $N$. ilheuense is a primary invader of Passifloraceae fruit or flower bud, once the trap was placed close to a Passifloraceae plantation (STRIKIS, 2011).

Except for $\boldsymbol{N}$. ilheuense, all the other species related in this study are poliphagous, what could make difficult to control the populations of such species. In crops the control is easier to achieve, but would be hard to accomplish in nature due to the widespread distribution of the species and to the polyphagy presented. The number of specimens reared from fruits or captured in traps suggests that the population size is small or the fruits sampled are not the preferred hosts of these species, so a more intensive fruit sampling is needed and the diversification of fruits sampled is also important in order to better evaluate the population dynamics of these species.

From the puparia obtained from the fruits were recovered 41 females of Neosilba. All the fruitfly specimens are in the collection of Pedro Carlos Strikis, except those used to species descriptions that are deposited at Zoology museum of the Universidade de São Paulo (MZUSP).

\section{ACKNOWLEDGMENTS}

Thanks to Fundação de Amparo à Pesquisa no Estado da Bahia (FAPESB) and Universidade Estadual de Santa Cruz (UESC) for the financial support.

\section{REFERENCES}

AGUIAR-MENEZES, E.L. et al. Susceptibilidade de seis cultivares de café arábica às moscas-das-frutas (Diptera: Tephritoidea) 
em sistema orgânico com e sem arborização em Valença, RJ. Neotropical Entomology, v.36, n.2, p.268-273, 2007.

ARAÚJO, E.L.; ZUCCHI, R.A. Hospedeiros e níveis de infestação de Neosilba pendula (Bezzi) (Diptera: Lonchaeidae) na região de Mossoró/Assu, RN. Arquivos do Instituto Biológico, v.69, n.2, p.91-94, 2002. Available from: <http://www.biologico.sp.gov.br/ docs/arq/V69_2/araujo_II.pdf >. Accessed: jun. 13, 2004.

BITTENCOURT, M.A.L. et al. Novos registros de espécies de Neosilba (Diptera: Lonchaeidae) na Bahia. Neotropical Entomology, v.35, n.2, p.282-283, 2006.

GARCIA, F.R.M.; NORRBOM, A.L. Tephritoid flies (Diptera, Tephritoidea) and their plant hosts from the state of Santa Catarina in southern Brazil. Florida Entomologist, v.94, n.2, p.151-157, 2011. Available from: <http://www.bioone. org/toc/flen/94/2>. Accessed: abr. 02, 2012. doi: http://dx.doi. org/10.1653/024.094.0205.

LOPES, E.B. et al. Moscas frugívoras (Tephritidae e Lonchaeidae) ocorrência em pomares comerciais de tangerina da Paraíba. Revista Tecnologia \& Ciência Agropecuária, v.1, n.2, p.31-37, 2007. Available from: <http://www.emepa.org.br/revista/volumes/ tca_v1_n2/tca05_mosca_frugivora.pdf>. Accessed: abr. 02, 2012.

LOURENÇÃO, A.L. et al. Comportamento de clones de mandioca em relação à infestação por Neosilba perezi (Romero \& Ruppell) (Diptera: Lonchaeidae). Scientia Agricola, v.53, n.2-3, p.304-309, 1996. Available from: <http://www.scielo.br/scielo.php?script=sci issuetoc\&pid=0103-901619960002\&lng=en\&nrm=iso $>$. Accessed: mar. 23, 2012. doi: 10.1590/S0103-90161996000200019.

McALPINE, J.F.; STEYSKAL, G.C. A revision of Neosilba McAlpine with a key to the world genera of Lonchaeidae (Diptera). Canadian Entomologist, v.114, n.2, p.105-137, 1982.

MONTES, S.M.N.M. et al. Infestación natural de Lonchaeidae (Diptera) en variedades de melocotón. Revista Colombiana de Entomologia, v.36, n.2, p.223-228, 2010. Available from: <http:// www.scielo.org.co/pdf/rcen/v36n2/v36n2a08.pdf $>$. Accessed: mar. 23, 2012.

QUERINO, R.B. et al. Interação de larvas frugívoras (Diptera, Tephritidae e Lonchaeidae) e seus hospedeiros na Reserva Florestal Adolpho Ducke, Manaus, Amazonas, Brasil. Teresina: Embrapa Meio-Norte, 2010. 30p. (Boletim de Pesquisa e Desenvolvimento, 88). Available from: <http://www.cpamn. embrapa.br/publicacoes/boletim/2010/BOLP88.pdf>. Accessed: jun. 23, 2012.
RAGA, A. et al. Host ranges and infestation indices of fruit flies (Tephritidae) and lance flies (Lonchaeidae) en São Paulo state, Brazil. Florida Entomologist, v.94, n.4, p.787-794, 2011. Available from: <http://www.bioone.org/toc/flen/94/4>. Accessed: mar. 24, 2012. doi: http://dx.doi.org/10.1653/024.094.0409.

SANTOS, W.S. et al. Registro de Neosilba zadolicha McAlpine \& Steyskal (Diptera: Lonchaeidae) em umbú-cajá (Anacardiaceae). Neotropical Entomology, v.33, n.5, p.653-654, 2004.

STRIKIS, P.C.; LERENA, M.L.M. A new species of Neosilba (Diptera, Lonchaeidae) from Brazil. Iheringia, Série Zoologia, v.99, n.3, p.273-275, 2009

STRIKIS, P.C.; PRADO, A.P. A new species of genus Neosilba (Diptera: Lonchaeidae). Zootaxa, v. 828, p.1-4, 2005.

STRIKIS, P.C.; PRADO, A.P. Lonchaeidae associados a frutos de nêspera, Eryobotria japônica (Thunb.) Lindley (Rosaceae), com a descrição de uma espécie nova de Neosilba (Diptera: Tephritoidea). Arquivos do Instituto Biológico, v.76, n.1, p.4954, 2009. Available from: <http://www.biologico.sp.gov.br/docs/ arq/v76_1/strikis.pdf>. Accessed: mar. 24, 2012.

STRIKIS, P.C.; PRADO, A.P. Neosilba (Tephritoidea: Lonchaeidae) species reared from coffee in Brazil, with description of a new species. In: SUGAYAMA, R.L. et al. INTERNATIONAL SYMPOSIUM ON FRUIT FLIES OF ECONOMIC IMPORTANCE: from basic to applied knowledge, 7., 2008, Salvador, BA. Proceedings... Salvador: SBPC, 2008. p.187-193.

STRIKIS, P.C. Description of 11 new species of genus Neosilba (Diptera: Lonchaeidae) from Brazil, its hosts and geographical distribution. Trends of Entomology, v.7, p.67-79, 2011.

UCHÔA, M.A. Fruit flies (Diptera: Tephritoidea): Biology, host plants, natural enemies, and the implications to their natural control. In: SOLONESKI, S.; LARRAMENDY, M.L. Integrated pest management and pest control: current and future tactics. Rijeka: InTech, 2012. Cap.12, p.271-300. Available from: <http:// cdn.intechopen.com/pdfs/29609/InTech-Fruit_flies_diptera_ tephritoidea_biology_host_plants_natural_enemies_and_the_ implications_to_their_natural_control.pdf >. Accessed: May. 08, 2012.

UCHÔA-FERNANDES, M.A. et al. Biodiversity of frugivorous flies (Diptera: Tephritoidea) captured in citrus groves, Mato Grosso do Sul, Brazil. Neotropical Entomology, v.32, n.2, p.239-246, 2003. 